CSDM Views 15

\title{
On the modalities of Ukraine's cooperation with Euro-Atlantic partners in addressing future security threats and challenges
}

\author{
Todor Tagarev
}


Todor Tagarev, On the modalities of Ukraine's cooperation with Euro-Atlantic partners in addressing future security threats and challenges

Summary: Speaking on the first panel on "Ukraine and International Organizations: Responding to Common Challenges and Threats" at the international conference on "The Role of International Organizations in the National Security of Ukraine" Dr. Tagarev emphasises the possibilities and potential benefits for Ukraine from being more proactive in its defence cooperation with NATO and the European Union.

Тодор Тагарев, Относно модалностите на сътрудничеството на Украйна с Евроатлантическите партньори за посрещането на бъдещи заплахи и предизвикателства за сигурността.

Резюме: В изложението си на международната конференция "Ролята на международните организации за националната сигурност на Украйна”, панел 1: "Украйна и международните организации в отговора на общи предизвикателства и заплахи", авторът подчертава възможностите и потенциалните ползи за Украйна от едно про-активно отбранително сътрудничество с НАТО и Европейския съюз.

cc) (i) $\ominus$ This text is licensed under a Creative Commons Attribution-Noncommercial-No EY NO NO Derivative 2.5 Bulgaria License

Editors: Todor Tagarev, Velizar Shalamanov, Venelin Georgiev, Valeri Ratchev 
Your Excellencies, Colleagues,

I am thankful to the Razumkov Centre ${ }^{1}$ and the NATO Liaison Office in Kyiv for the opportunity to get back to Kyiv after a break of about a year and to share with you some thoughts on the modalities of the cooperation of Ukraine with international organizations in responding to current and foreseeable security challenges and threats.

Let me start by stating that in the last decade or so Ukraine is finding its particular way and position on the international arena. From the perspective of a Western observer that way may seem more complex and oblique than it might have been. We need to admit and accept that this is the Ukrainian way.

In its particular approach to security, Ukraine cooperates with numerous international organizations. It is in the interest of Ukraine to be seen and perceived by the international community and international organizations as a valuable, reliable contributor to international stability and security.

Ukraine is also interested in an active Euro-Atlantic community that remains able and willing to deal with security threats and challenges of the current day, as well as of the future.

If we accept that there is a mutual interest in cooperation, let me turn to the modalities of this cooperation. There are possibilities in diplomacy, intelligence, economic, cultural exchanges and so on. However, with by background in mind, I would rather focus on the field of defence and the military.

In my personal observations, the international community, including the Euro-Atlantic community, has benefited from the contribution of Ukraine to peace operations. Ukraine has also benefited from its exchange with NATO and the assistance received by the Alliance, its participation in the Partnership for Peace programme, and exchanges on a bi-lateral basis with allied and partner countries.

This is visible when one looks at:

- planning and defence management approaches, methods, and tools applied by the Ukrainian defence establishment;

- organization of the armed forces;

- operational concepts;

- training standards;

- interoperability requirements and standards.

This is a remarkable achievement that, among others, provided for the effective contribution of the Armed Forces of Ukraine to international peace and stability operations.

We have to admit, though, that the mutual benefits of cooperation could be much higher, in particular in view of the persistent economic and financial difficulties, the European Union "Pooling

$1 \quad$ http://www.razumkov.org.ua/eng/index.php. 
\& Sharing" 2 and NATO's Smart Defence initiative, to which the NATO Deputy Secretary General Alexander Vershbow just referred. ${ }^{3}$

The Euro-Atlantic community is open for such cooperation. The overwhelming number of activities of NATO are open to partner countries, such as Ukraine. That applies to emerging security challenges such as energy and cyber security, as well as to traditional processes of defining future requirements and the cooperative development of responses-including, but limited to technologies and materiel- to the future threats and challenges.

The utilisation of a larger part of these opportunities depends on the attitude and activity of Ukraine. Ukraine can be more active in NATO initiatives, programmes, and projects, particularly at the front end of the process of developing defence capabilities. That can be realised through:

- better understanding of the logic and the technicalities of the NATO capability-based defence planning; ${ }^{4}$

- involvement in studies aimed to define and harmonise operational and system requirements;

- involvement in the development of standards;

- strengthening the industrial cooperation.

I have no doubts that Ukraine has the capacity to participate effectively in such activities. Being more active would allow Ukraine to find its proper-and I would presume, more prestigious-role in the international cooperation aiming to address future security challenges and threats.

2 See, for example, 'Pooling and Sharing' activities of the European Defence Agency at www.eda.europa.eu/aboutus/whatwedo/pooling-and-sharing (16 September 2013).

3 Alexander Vershbow, Video Address by NATO Deputy Secretary General to the international conference on international organizations and the national security of Ukraine, Kyiv, 17 September 2013.

$4 \quad$ For example, by joining the 'smart defence' project ADAPT. See for details the website of the NATO Communications and Information Agency, http://www.ncia.nato.int/events/Pages/130410-ADAPT.aspx. 